\title{
CONSUMPTION OF DIFFERENT TYPES OF BAKERY PRODUCTS AND ITS EFFECT ON VISCERAL FAT AREA IN HEALTHY POPULATION
}

\author{
Martina Gažarovál, Petra Lenártovál, Jana Kopčekovál, Jana Mrázovál, \\ Mária Holovičovál, Zuzana Chlebován , Joanna Wyka \\ ${ }^{1}$ Slovak University of Agriculture, Faculty of Agrobiology and Food Resources, Department of Human \\ Nutrition, Tr. A. Hlinku 2, 94976 Nitra, Slovak Republic \\ ${ }^{2}$ Slovak University of Agriculture, Faculty of Agrobiology and Food Resources, Department of Genetics \\ and Plant Breeding, Tr. A. Hlinku 2, 94976 Nitra, Slovak Republic \\ ${ }^{3}$ Wroclaw University of Environmental and Life Sciences, Faculty of Food Science, Department of Human \\ Nutrition, Wroclaw, Poland
}

\begin{abstract}
Background. Bread is one of the world's most consumed food commodity. However, in the last years consumption of bread and bakery products has declined, especially in the Western population. The reason for concern is the weight gain and presence of gluten in these products. Gluten is unacceptable in the diet only in patients with celiac disease who are forced adhere the gluten-free diet all the time. The consequences of gluten-free diet in healthy people are the subject of many recent studies.

Objective. The aim of this study was to evaluate the changes of visceral fat area in the general population after 6 weeks of consumption of gluten-free, gluten-containing and whole-grain bread and other bakery products.

Material and Methods. The study group consisted of 120 volunteers divided into four subgroups each with 30 subjects. Anthropometric measurements were made using the InBody 720 (Biospace Co. Ltd., Seoul, Republic of Korea). We used the Lookin'Body 3.0 software to process the results. The collected data from anthropometric measurements were evaluated statistically and graphically in Microsoft Office Excel 2010 (Los Angeles, CA, USA).

Results. After the intervention we found out that visceral fat area values increased in probands consuming gluten-free and gluten-containing bakery products, but these changes were not significant $\left(\mathrm{P}>0.05 ; 72.7 \pm 29.18 \mathrm{~cm}^{2} \mathrm{vs} 73.26 \pm 30.32\right.$ $\mathrm{cm}^{2}$ and $69.6 \pm 34.06 \mathrm{~cm}^{2}$ vs $70.34 \pm 32.33 \mathrm{~cm}^{2}$, respectively). In whole-grain and control group we observed a reduction in visceral fat area, in the control group there was a significant change $\left(\mathrm{P}>0.05-91.58 \pm 33 \mathrm{~cm}^{2}\right.$ vs $90.47 \pm 34.37 \mathrm{~cm}^{2}$ and $\mathrm{P}<0.05-77.3 \pm 21.65 \mathrm{~cm}^{2}$ vs $75.56 \pm 21.87 \mathrm{~cm}^{2}$, respectively). After the intervention the visceral fat area values increased in gluten-free group in $57 \%$ of subjects, in gluten group in $73 \%$ of subjects and in the whole-grain group in $43 \%$ of volunteers . Although visceral fat area values had inceased in gluten-free and gluten-containing groups, the number of probands with reference values increased from $80 \%$ to $86 \%$ in the gluten-free group and from $43 \%$ to $66 \%$ in the gluten-containing group. In the whole-grain group we found decrease in number of subjects with reference values of visceral fat area (from $70 \%$ to $63 \%$ ). There were no changes in the control group ( $86 \%$ vs. $86 \%$ ).
\end{abstract}

Conclusions. Consumption of different types of bakery products has mostly changed the visceral fat area values in a positive direction.

Key words: bakery products, bread, gluten, gluten-free, InBody 720, visceral fat area, whole-grain

\section{STRESZCZENIE}

Wstęp. Chleb jest jednym z najczęściej spożywanych produktów żywnościowych na świecie. Jednak w ostatnich latach spadło spożycie pieczywa, zwłaszcza w populacji zachodniej. Powodem rezygnacji z konsumpcji jest obawa o przyrost masy ciała i obecność glutenu w tych produktach. Gluten jest niedopuszczalny w diecie tylko u pacjentów z celiakią, którzy są zmuszeni stosować dietę bezglutenową. Konsekwencje stosowania diety bezglutenowej u zdrowych ludzi są przedmiotem wielu ostatnich badań.

Cel. Celem badania była ocena zmian w obszarze trzewnej tkanki tłuszczowej w grupie badanej po 6 tygodniach konsumpcji: chleba bezglutenowego, chleba zawierającego gluten i chleba pełnoziarnistego oraz innych produktów piekarniczych.

Corresponding author: Joanna Wyka, Uniwersytet Przyrodniczy we Wrocławiu, Wydział Biotechnologii i Nauk o Żywności, Katedra Żywienia Człowieka / Wroclaw University of Environmental and Life Sciences, Faculty of Biotechnology and Food Science, Department of Human Nutrition, Chełmońskiego street 37/41, 51-630 Wroclaw, Poland, phone: +48 7132077 57, fax: +48 7132077 58, e-mail: joanna.wyka@upwr.edu.pl 


\begin{abstract}
Materiał i metody. Grupa badana składała się ze 120 ochotników podzielonych na cztery podgrupy, w każdej po 30 osób. Pomiary antropometryczne wykonano przy użyciu InBody 720 (Biospace Co. Ltd., Seoul, Republika Korei). Do analizy wyników wykorzystano oprogramowanie Lookin'Body 3.0. Zebrane dane z pomiarów antropometrycznych zostały ocenione statystycznie i graficznie w Microsoft Office Excel 2010 (Los Angeles, Kalifornia, USA).

Wyniki. Po interwencji dietetycznej wykazano, że wartości trzewnej tkanki tłuszczowej wzrosły u osób spożywających produkty piekarnicze bezglutenowe i zawierające gluten, ale zmiany te nie były istotne statystycznie ( $p>0,05,72,7 \pm 29,18 \mathrm{~cm}^{2}$ w porównaniu z 73,26 $\pm 30,32 \mathrm{~cm}^{2}$ i $69,6 \pm 34,06 \mathrm{~cm}^{2}$ vs $70.34 \pm 32,33 \mathrm{~cm}^{2}$, odpowiednio). W grupie osób spożywających chleb pełnoziarnisty i kontrolnej obserwowano zmniejszenie trzewnej tkanki thuszczowej, w grupie kontrolnej nastąpiła istotna zmiana (p>0,05 - 91,58 $\pm 33 \mathrm{~cm}^{2}$ wobec $90,47 \pm 34,37 \mathrm{~cm}^{2}$ i p $<0,05-77,3 \pm 21,65 \mathrm{~cm}^{2}$ vs 75,56 $\pm 21,87 \mathrm{~cm}^{2}$, odpowiednio). Po interwencji dietetycznej wartości trzewnej tkanki tluszczowej zwiększyły się w grupie spożywającej chleb bezglutenowy u 57\% badanych, w grupie spożywającej chleb z glutenem u $73 \%$ badanych oraz w grupie osób spożywającej chleb pełnoziarnisty u $43 \%$ ochotników. Chociaż wartości trzewnej tkanki thuszczowej były obecne w grupach osób spożywających chleb bez glutenu i zawierających gluten, liczba uczestników o wartościach referencyjnych prawidłowych wzrosła z $80 \%$ do $86 \% \mathrm{w}$ grupie bezglutenowej i z $43 \%$ do $66 \% \mathrm{w}$ grupie zawierającej gluten. W grupie osób spożywających chleb z pełnymi ziarnami stwierdzono zmniejszenie liczby osób z wartościami referencyjnymi prawidłowymi trzewnej tkanki tłuszczowej (z 70\% do 63\%). W grupie kontrolnej nie zanotowano zmian (86\% vs. 86\%).

Wnioski. Spożywanie różnych rodzajów produktów piekarniczych w większości zmieniło zawartość trzewnej tkanki tłuszczowej u osób poddanych badaniu.
\end{abstract}

Slowa kluczowe: produkty piekarnicze, chleb, gluten, bezglutenowy, InBody 720, trzewna tkanka thuszczowa, petnoziarnisty chleb

\section{INTRODUCTION}

White bread derived from wheat is one of the main staple consumed in Western populations. As a result of its nutritive value, price and simplicity of usage, it has become the basis of all civilizations' diets. It contributes to total energy intake and delivers dietary fiber, proteins and vitamins and minerals [50,64]. The term whole-grain has been applied to foods that contain the intact grain and to foods containing the appropriate proportions of all the milled grain constituents [30]. Because of the belief that foods rich in fiber are low in fat, many authorities have recommended consumption of grain products to control weight [35]. Whole grains have positive effect on weight control thanks to a sense of satiety [65]. Results from several studies suggest that consumption of whole-grain products increase satiety and reduce energy intake and contribute to weight loss or maintain optimal body weight [55]. Cereal foods are good sources of dietary fiber - barley and oats provide $\beta$-glucans [16]. Bread is mainly produced from wheat and rye flours containing prolamins and a protein fraction responsible for structure and quality (gluten). However, there is a group of people for whom consumption of prolamins - gliadins of wheat, secalins of rye, hordeins of barley and avenins of oats - causes disorders such as coeliac disease, allergy and non-celiac gluten sensitivity $[17,26]$. Coeliac disease is a lifelong disease caused by the intolerance to gluten [62] and has become an intensively researched topic over the last years [18]. In recent years there has been an increasing interest on gluten-free foodstuffs [34]. The proportion of people on a gluten-free diet exceeds in more than five times the number of those who require gluten exclusion as a treatment [11]. Gluten-free diet is currently one of the three most popular food regimens in the world [9]. If healthy people decide to follow a gluten-free diet because they consider it is healthier, they should be very careful to accomplish the nutrition balance. The nutritional value of gluten-free products is poor [47]. Researchers are motivated to investigate new ingredients and technologies to be applied in gluten-free bread-making in order to improve the quality and nutritive value of these products $[3,10$, $13,25,57]$. Gluten-free breads had a higher glycaemic index than the conventional breads [12], had great divergences in fat and protein composition and their contribution to the daily protein intake is very low [59]. Almost all the gluten-free products were high in available carbohydrates, with approximately $50 \%$ of sugar content in cookies, breakfast and sweet products, which results in a high glycaemic load [44]. Bread is also one of the most restricted foods in popular hypocaloric diets. It is considered dangerous and caloric and is included in the list of forbidden foods by those trying to lose weight $[40,41]$. Dietary habits play a crucial role in the development of overweight and obesity [8]. Their prevalence has increased in developed countries. Obesity is a serious health condition significantly associated with higher mortality and morbidity [31] and highly prevalent metabolic disorder that is characterized by excessive body fat mass. It produces adipokines that are strongly associated with much comorbidity, e.g. type 2 diabetes and metabolic syndrome [1]. Abdominal obesity and excess visceral fat are independent risk factors for cardiovascular diseases [15], diabetes mellitus and total mortality [29, 60]. The severity of obesity is evaluated by different methods. Measurement of visceral fat area is also reported to be useful for predicting atherosclerosis 
[19]. Visceral fat area is important factor used in the assessment of cardiometabolic risk and is correlated with the metabolic syndrome even at the normal body mass index indicating the absence of obesity $[5,28]$.

The aim of the study was to evaluate the effect of consumption of different types of bread and bakery products on visceral fat area and find the relation between gluten-free, gluten-containing and wholegrain bakery products consumption and changes in abdominal fat gain.

\section{MATERIAL AND METHODS}

One hundred and twenty adults from the general population took part in the study (42 males and 78 females, age between 20 and 55 years). The requirement for participation in the research was informed consent of volunteers with all the study and measurement conditions which they will have to complete during the research. All participants signed written informed consent to participate in the study. Probands with the present severe disease or with recommended special dietary regimen were excluded. The trial was approved by the Ethic Committee at the Specialized Hospital St. Zoerardus Zobor, n.o. (protocol no. 012911/2016). Participants were divided into four study subgroups gluten-free, gluten-containing, whole-grain and control group. Each subgroup was composed of thirty adults. Their characteristics are shown in Table 1. Participants of gluten-free group consumed gluten-free bread and gluten-free bakery products, however were not allowed total gluten-free diet. Participants of gluten group consumed gluten-containing bread and bakery products and participants of whole-grain group consumed wholegrain bread and bakery products. The amount of bread and bakery product for consumption was determined according to the recommended consumption of food for the Slovak population as follows: women consumed 150200 grams per day; men 200-250 grams per day during 6-week period. All participants were asked not to change their eating habits and also not to change their habits related to the physical activity. Volunteers had a total of 3 anthropometric measurements (first measurement before consumption, second measurement after the 6-week consumption of bread and bakery products, and third measurement two months after end of consuming chosen products). The anthropometric measurements were made by using InBody 720 (Biospace Co. Ltd., Seoul, Republic of Korea). Each of the participants was informed with the measurement procedure, explained the possible risks of measuring in the case of pregnancy or having an artificial pacemaker at the heart. Before the measurement, participants were asked to excrete and refrain from drinking excessive amounts of water [67]. At the same time each participant signed informed consent for the measurement procedure and also agreed to the processing of personal data. One woman did not complete the trial (whole-grain group). We used the Lookin'Body 3.0 software to process the results. We observed the visceral fat area (VFA). Its excessive amount causes the metabolic and cardiovascular diseases. In the examination, VFA is defined as the cross-sectional area of visceral fat found in the abdomen. VFA values can be divided into 6 categories: values below $40 \mathrm{~cm}^{2}$ are evaluated as low visceral fat area; values between $41-70 \mathrm{~cm}^{2}$ mean optimal visceral fat area; values between $71-100 \mathrm{~cm}^{2}$ expressed limit visceral fat area; values ranged between $101-130 \mathrm{~cm}^{2}$ mean border visceral fat area; values between 131-160 $\mathrm{cm}^{2}$ mean high visceral fat area and values above 160 $\mathrm{cm}^{2}$ mean extreme visceral fat area. We evaluated the collected data from the anthropometric measurements statistically and graphically in Microsoft Office Excel 2010 (Los Angeles, CA, USA). The changes in different groups were performed using Pared Student t-test and the data were presented as mean \pm standard deviation (SD). The levels of statistical significance were set at $\mathrm{P}<0.05(*), \mathrm{P}<0.01(* *), \mathrm{P}<0.001(* * *)$.

\section{RESULTS AND DISCUSSION}

The basic characteristics of the study participants are shown in Table 1. The sample of probands consisted of 120 people from the general population without any gender difference. The mean age of the study group was $31.9 \pm 9.18$ years in the range of $20-55$ years.

Table 1. The basic characteristics of the study groups (age)

\begin{tabular}{|c|c|c|c|c|c|c|c|c|c|}
\hline \multirow{2}{*}{ years } & \multicolumn{3}{|c|}{ all participants } & \multicolumn{3}{|c|}{ gluten-free group } & \multicolumn{3}{|c|}{ gluten group } \\
\hline & all & female & male & all & female & male & all & female & male \\
\hline $\mathrm{n}$ & 120 & 78 & 42 & 30 & 27 & 3 & 30 & 17 & 13 \\
\hline mean & 31.90 & 31.64 & 32.38 & 29.73 & 29.11 & 35.33 & 30.73 & 31.76 & 29.38 \\
\hline$\pm \mathrm{SD}$ & 9.18 & 9.42 & 8.8 & 7.29 & & & 8.69 & & \\
\hline \multirow{2}{*}{ years } & \multicolumn{3}{|c|}{ whole-grain group } & \multicolumn{3}{|c|}{ control group } & & & \\
\hline & all & female & male & all & female & male & & & \\
\hline $\mathrm{n}$ & 30 & 12 & 18 & 30 & 22 & 8 & & & \\
\hline mean & 39.70 & 44.08 & 36.78 & 27.43 & 27.86 & 26.25 & & & \\
\hline$\pm \mathrm{SD}$ & 8.63 & & & 7.27 & & & & & \\
\hline
\end{tabular}

Abbreviations: $n$-number of participants; $\pm S D$ - standard deviation 
Participants were divided into 6 categories according to VFA values in each subgroup (Table 2). At the beginning of the study before intervention we recorded the highest number of probands in the low VFA category in the gluten group (33\%), but also with border VFA values (20\%), the most probands with optimal values of VFA were in gluten-free group $(57 \%)$, the most limit VFA values had probands in control group (53\%) and whole-grain group had at the beginning of the study the majority of subjects with high $(10 \%)$ and extreme (3\%) VFA values. During study there were the changes in the representation of subjects in each category. In gluten-free group there was no proband with low VFA after 6 weeks of consumption. The greatest change in this category occurred in the gluten group, where from the initial $33 \%$ of the probands the number decreased to $10 \%$, which means that their VFA values increased with consumption of gluten-containing bakery products.

Table 2. Representation of participants in VFA categories during study

\begin{tabular}{|c|c|c|c|c|c|c|c|c|c|c|}
\hline \multicolumn{3}{|c|}{ Category of VFA $\left(\mathrm{cm}^{2}\right)$} & \multicolumn{2}{|c|}{ baseline } & \multicolumn{3}{|c|}{ after 6 weeks of consumption } & \multicolumn{3}{|c|}{2 months after end of consumption } \\
\hline \multicolumn{2}{|c|}{ all participants } & $\mathrm{n}$ & $\%$ & mean & $\mathrm{n}$ & $\%$ & mean & $\mathrm{n}$ & $\%$ & mean \\
\hline low & $\leq 40$ & 12 & 10 & 37.13 & 5 & 4 & 34.02 & 5 & 4 & 35.97 \\
\hline optimal & $41-70$ & 43 & 36 & 56.18 & 51 & 43 & 54.09 & 49 & 41 & 54.68 \\
\hline limit & $71-100$ & 41 & 34 & 84.69 & 40 & 33 & 83.92 & 41 & 34 & 85.68 \\
\hline border & $101-130$ & 16 & 13 & 113.63 & 16 & 13 & 112.78 & 15 & 13 & 114.04 \\
\hline high & $131-160$ & 7 & 6 & 141.87 & 6 & 5 & 140.17 & 7 & 6 & 141.19 \\
\hline extreme & $>160$ & 1 & 1 & 190.81 & 2 & 2 & 178.83 & 2 & 2 & 177.89 \\
\hline \multicolumn{2}{|c|}{ male group } & $\mathrm{n}$ & $\%$ & mean & $\mathrm{n}$ & $\%$ & mean & $\mathrm{n}$ & $\%$ & mean \\
\hline low & $\leq 40$ & 4 & 10 & 35.14 & 3 & 7 & 31.01 & 2 & 5 & 34.82 \\
\hline optimal & $41-70$ & 14 & 33 & 56.14 & 15 & 36 & 55.32 & 15 & 36 & 52.78 \\
\hline limit & $71-100$ & 13 & 31 & 86.51 & 12 & 29 & 85.03 & 14 & 33 & 86.99 \\
\hline border & $101-130$ & 8 & 19 & 114.41 & 9 & 21 & 112.05 & 8 & 19 & 116.36 \\
\hline high & $131-160$ & 2 & 5 & 149.43 & 2 & 5 & 147.3 & 1 & 2 & 146.11 \\
\hline extreme & $>160$ & 1 & 2 & 190.81 & 1 & 2 & 190.44 & 2 & 5 & 177.89 \\
\hline \multicolumn{2}{|c|}{ female group } & $\mathrm{n}$ & $\%$ & mean & $\mathrm{n}$ & $\%$ & mean & $\mathrm{n}$ & $\%$ & mean \\
\hline low & $\leq 40$ & 8 & 10 & 38.13 & 2 & 3 & 38.53 & 3 & 4 & 36.74 \\
\hline optimal & $41-70$ & 29 & 37 & 56.19 & 36 & 46 & 53.58 & 34 & 44 & 55.51 \\
\hline limit & $71-100$ & 28 & 36 & 83.84 & 28 & 36 & 83.44 & 27 & 35 & 85 \\
\hline border & $101-130$ & 8 & 10 & 112.86 & 7 & 9 & 113.72 & 7 & 9 & 111.38 \\
\hline high & $131-160$ & 5 & 6 & 138.84 & 4 & 5 & 136.61 & 6 & 8 & 140.37 \\
\hline extreme & $>160$ & 0 & 0 & 0 & 1 & 1 & 167.22 & 0 & 0 & 0 \\
\hline \multicolumn{2}{|c|}{ gluten-free group } & $\mathrm{n}$ & $\%$ & mean & $\mathrm{n}$ & $\%$ & mean & $\mathrm{n}$ & $\%$ & mean \\
\hline low & $\leq 40$ & 1 & 3 & 37.8 & 0 & 0 & 0 & 0 & 0 & 0 \\
\hline optimal & $41-70$ & 17 & 57 & 55.42 & 19 & 63 & 56.04 & 18 & 60 & 57.13 \\
\hline limit & $71-100$ & 7 & 23 & 81.39 & 7 & 23 & 84.53 & 7 & 23 & 85.96 \\
\hline border & $101-130$ & 3 & 10 & 112.94 & 2 & 7 & 117.04 & 2 & 7 & 104.38 \\
\hline high & $131-160$ & 2 & 7 & 146.23 & 1 & 3 & 139.92 & 3 & 10 & 143.59 \\
\hline extreme & $>160$ & 0 & 0 & 0 & 1 & 3 & 167.22 & 0 & 0 & 0 \\
\hline \multicolumn{2}{|c|}{ gluten group } & $\mathrm{n}$ & $\%$ & mean & $\mathrm{n}$ & $\%$ & mean & $\mathrm{n}$ & $\%$ & mean \\
\hline low & $\leq 40$ & 10 & 33 & 36.88 & 3 & 10 & 29.72 & 5 & 17 & 35.97 \\
\hline optimal & $41-70$ & 7 & 23 & 54.6 & 13 & 43 & 47.99 & 11 & 37 & 50.7 \\
\hline limit & $71-100$ & 6 & 20 & 83.15 & 7 & 23 & 81.56 & 8 & 27 & 83.34 \\
\hline border & $101-130$ & 6 & 20 & 114.98 & 6 & 20 & 114.4 & 5 & 17 & 120.3 \\
\hline high & $131-160$ & 1 & 3 & 148.27 & 1 & 3 & 139.7 & 1 & 3 & 146.11 \\
\hline extreme & $>160$ & 0 & 0 & 0 & 0 & 0 & 0 & 0 & 0 & 0 \\
\hline \multicolumn{2}{|c|}{ whole-grain group } & $\mathrm{n}$ & $\%$ & mean & $\mathrm{n}$ & $\%$ & mean & $\mathrm{n}$ & $\%$ & mean \\
\hline low & $\leq 40$ & 0 & 0 & 0 & 1 & 3 & 40.03 & 0 & 0 & 0 \\
\hline optimal & $41-70$ & 9 & 30 & 58.51 & 9 & 30 & 59.04 & 8 & 28 & 54.55 \\
\hline limit & $71-100$ & 12 & 40 & 86.7 & 10 & 33 & 85.23 & 10 & 34 & 86.12 \\
\hline border & $101-130$ & 5 & 17 & 114.45 & 6 & 20 & 112.39 & 7 & 24 & 112.34 \\
\hline high & $131-160$ & 3 & 10 & 139.15 & 3 & 10 & 141.89 & 2 & 7 & 135.94 \\
\hline extreme & $>160$ & 1 & 3 & 190.81 & 1 & 3 & 190.44 & 2 & 7 & 177.89 \\
\hline \multicolumn{2}{|c|}{ control group } & $\mathrm{n}$ & $\%$ & mean & $\mathrm{n}$ & $\%$ & mean & $\mathrm{n}$ & $\%$ & mean \\
\hline low & $\leq 40$ & 1 & 3 & 38.98 & 1 & 3 & 40.91 & 0 & 0 & 0 \\
\hline optimal & $41-70$ & 10 & 33 & 56.47 & 10 & 33 & 53.86 & 12 & 40 & 54.72 \\
\hline limit & $71-100$ & 16 & 53 & 85.21 & 16 & 53 & 83.86 & 16 & 53 & 86.45 \\
\hline border & $101-130$ & 2 & 7 & 108.57 & 2 & 7 & 104.85 & 1 & 3 & 113.91 \\
\hline high & $131-160$ & 1 & 3 & 134.88 & 1 & 3 & 135.72 & 1 & 3 & 139.59 \\
\hline extreme & $>160$ & 0 & 0 & 0 & 0 & 0 & 0 & 0 & 0 & 0 \\
\hline
\end{tabular}


With respect to standard bakery products based on wheat flour, gluten-free bread contains smaller amounts of minerals, vitamins and dietary fiber [2]. Gluten-free bread provides twice as much fat, mainly saturated fat in comparison to its equivalents with gluten [48]. Gluten-free diet has been popularized among people who want to lose weight and gluten-free consumers stand out the idea that gluten-free products are healthier and gluten-free diet improve their health [22]. The reason for gluten-free products consumption was $27 \%$ to lose weight [24]. Considering glutenfree products suitable for weight loss could lead to overconsumption of these energy-rich products and could result in promoting weight gain $[23,66]$. Researchers found an excess intake of total energy, animal protein and fat and a lower intake of dietary fiber by following a gluten-free diet [42, 48, 54 ]. Higher intake of fat could be caused by ingredients used for gluten-free bread making [63]. Gluten-free bread contains twice amount of fat in comparison to white bread [48]. From this reason, people who want weight gain think that following a gluten-free diet as a good alternative [52]. Changes of VFA values of study subgroups expressed Table 3. In gluten-free group average values of VFA changed with a rising trend, an initial value of $72.7 \pm 29.18 \mathrm{~cm}^{2}$ has risen to $73.26 \pm 30.32 \mathrm{~cm}^{2}$ without statistical significance. It is interesting that the highest mean VFA value in this group was recorded two months after end of consumption $\left(75.65 \pm 29.01 \mathrm{~cm}^{2}\right)$ with a significant change compared to previous values $(\mathrm{P}<0.05)$. The highest individual VFA value was $167.22 \mathrm{~cm}^{2}$ detected during the second measurement in this subgroup. When compared to the control group there were no significant differences (Table 4) and no significant changes in VFA categories during consumption. The majority of probands had optimal or limit VFA values (63\% and $23 \%$, respectively).

Table 3. Changes of VFA during trial in the study groups

\begin{tabular}{|c|c|c|c|c|c|c|c|c|c|}
\hline & Baseline & $\begin{array}{c}\text { After } 6 \\
\text { weeks of } \\
\text { consumption }\end{array}$ & $\begin{array}{l}2 \text { months } \\
\text { after end of } \\
\text { consumption }\end{array}$ & Baseline & $\begin{array}{c}\text { After } 6 \\
\text { weeks of } \\
\text { consumption }\end{array}$ & $\begin{array}{c}2 \text { months } \\
\text { after end of } \\
\text { consumption }\end{array}$ & Baseline & $\begin{array}{c}\text { After } 6 \\
\text { weeks of } \\
\text { consumption }\end{array}$ & $\begin{array}{c}2 \text { months } \\
\text { after end of } \\
\text { consumption }\end{array}$ \\
\hline & \multicolumn{3}{|c|}{ all participants } & \multicolumn{3}{|c|}{ male group } & \multicolumn{3}{|c|}{ female group } \\
\hline $\mathrm{n}$ & 120 & 120 & 119 & 42 & 42 & 42 & 78 & 78 & 77 \\
\hline mean & 77.80 & 77.40 & 79.21 & 82.29 & 81.83 & 83.62 & 75.38 & 75.02 & 76.81 \\
\hline$\pm \mathrm{SD}$ & 30.68 & 30.73 & 31.04 & 35.10 & 34.74 & 35.63 & 27.96 & 28.29 & 28.20 \\
\hline $\max$ & 190.81 & 190.44 & 194.33 & 190.81 & 190.44 & 194.33 & 153.94 & 167.22 & 157.86 \\
\hline $\min$ & 27.31 & 19.36 & 31.24 & 27.31 & 19.36 & 31.24 & 32.97 & 36.15 & 32.01 \\
\hline med & 74.26 & 74.33 & 74.99 & 79.94 & 81.93 & 82.06 & 72.77 & 71.39 & 72.42 \\
\hline $\mathrm{P}$ & 0.32 & $0.00^{\mathrm{b}}$ & $0.02^{\mathrm{c}}$ & 0.55 & 0.05 & 0.21 & 0.43 & $0.00^{\mathrm{b}}$ & $0.04^{c}$ \\
\hline \multicolumn{2}{|c|}{ significance } & $* * *$ & * & & & & & $* *$ & $*$ \\
\hline
\end{tabular}

Table 3. Changes of VFA during trial in the study groups - continued

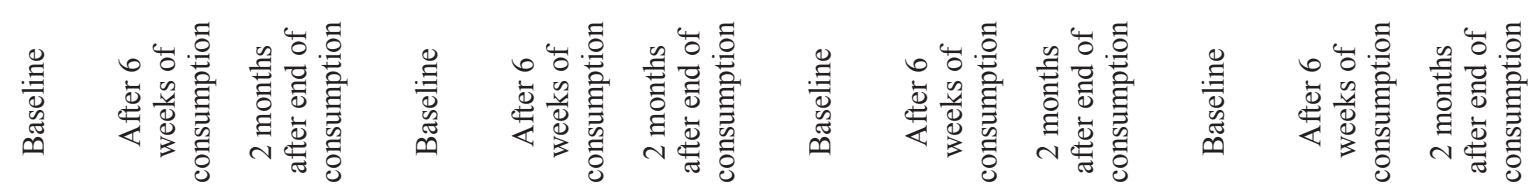

\begin{tabular}{|c|c|c|c|c|c|c|c|c|c|c|c|c|}
\hline \multirow[b]{2}{*}{$\mathrm{n}$} & \multicolumn{3}{|c|}{ gluten-free group } & \multicolumn{3}{|c|}{ gluten group } & \multicolumn{3}{|c|}{ whole-grain group } & \multicolumn{3}{|c|}{ control group } \\
\hline & 30 & 30 & 30 & 30 & 30 & 30 & 30 & 30 & 29 & 30 & 30 & 30 \\
\hline mean & 72.70 & 73.26 & 75.65 & 69.60 & 70.34 & 71.73 & 91.58 & 90.47 & 93.50 & 77.30 & 75.56 & 76.45 \\
\hline$\pm \mathrm{SD}$ & 29.18 & 30.32 & 29.01 & 34.06 & 32.33 & 32.53 & 33.00 & 34.37 & 35.50 & 21.65 & 21.87 & 22.83 \\
\hline $\max$ & 153.94 & 167.22 & 157.86 & 148.27 & 139.70 & 146.11 & 190.81 & 190.44 & 194.33 & 134.88 & 135.72 & 139.59 \\
\hline $\min$ & 37.80 & 41.07 & 41.50 & 27.31 & 19.36 & 31.24 & 42.36 & 40.03 & 45.11 & 38.98 & 40.91 & 43.53 \\
\hline med & 67.36 & 66.60 & 66.62 & 64.57 & 63.12 & 61.97 & 87.02 & 84.07 & 89.78 & 80.53 & 77.35 & 75.05 \\
\hline $\mathrm{P}$ & 0.42 & $0.02^{b}$ & $0.01^{\mathrm{c}}$ & 0.40 & 0.18 & 0.07 & 0.17 & $0.00^{\mathrm{b}}$ & 0.26 & $0.02^{\mathrm{a}}$ & 0.42 & 0.46 \\
\hline signific & & $*$ & $*$ & & & & & $* * *$ & & $*$ & & \\
\hline
\end{tabular}

Abbreviations: $n$ - number of participants; $\pm S D$ - standard deviation; max-maximum value; min - minimum value; med - the median value of a range of values; the levels of statistical significance chosen for the comparisons were $P<0.05(*), P<0.01(* *), P<0.001$ $(* * *) ; a$-intra-group differences after 6 -weeks consumption of bakery products; $b$-differences between data obtained after 6 weeks of consumption and post-intervention data; $c$-differences between baseline data and post-intervention data

From all probands in gluten group the most of them were in the category with low or border VFA before intervention (33\% and 20\%, respectively; Table 2). Due to the consumption of gluten-containing bakery products VFA values increased which was reflected in the shift of subjects between different VFA categories. At the beginning of the study $33 \%$ of participants had the low VFA values but after 6 weeks of consumption 
this number dropped to $10 \%$. VFA values of these subjects increased which means that these probands were ranked to category with optimal VFA (23\% at baseline, $43 \%$ after intervention).

In the other VFA categories there were no significant changes in participants' presence. Similarly to the gluten-free group also in this group the mean VFA values changed with increasing tendency (Table 3 ). The initial VFA values increased from $69.6 \pm 34.06$ $\mathrm{cm}^{2}$ to $70.34 \pm 32.33 \mathrm{~cm}^{2}$. None of the changes was significant. VFA values ranged between $19.36 \mathrm{~cm}^{2}$ and $148.27 \mathrm{~cm}^{2}$. Compared with the control group we did not find any statistically significant changes (Table 4). In general, increase in total bread consumption is associated with more weight gain. Bautista-Castaño et al. [6] found and suggest a dose-response relationship between the increase in white-bread consumption and weight gain. Gaining weight more than $2 \mathrm{~kg}$ were not associated with an increase in bread consumption, but decrease in white-bread consumption was associated with losing weight. In this study participants who decreased consumption of total bread increased the intake of fish, dairy products, vegetables, cereals and sweets, those who increased their bread consumption decreased the intake of these foods. FuenteArrillaga et al. [14] found that participants with the highest consumption of white bread $(\geq 6$ slices per day) significantly increased their risk of becoming overweight or obese in compare with those with the lowest consumption ( $\leq 3$ slices per week). Lean et al. [37] associated a greater intake of bread with less weight loss in postmenopausal women. However, Aston et al. [4] found that the presence of bread in the diet was associated with greater weight loss.

Table 4. Differences between study groups

\begin{tabular}{|c|c|c|c|c|c|c|}
\hline & Baseline & $\begin{array}{l}\text { After } 6 \text { weeks of } \\
\text { consumption }\end{array}$ & $\begin{array}{l}2 \text { months after end } \\
\text { of consumption }\end{array}$ & Baseline & $\begin{array}{l}\text { After } 6 \text { weeks of } \\
\text { consumption }\end{array}$ & $\begin{array}{l}2 \text { months after end } \\
\text { of consumption }\end{array}$ \\
\hline & \multicolumn{3}{|c|}{ gluten-free/gluten } & \multicolumn{3}{|c|}{ gluten-free/whole-grain } \\
\hline $\mathrm{P}$ & 0.71 & 0.72 & 0.63 & $0.04^{\mathrm{a}}$ & 0.07 & 0.09 \\
\hline significance & & & & $*$ & & \\
\hline & \multicolumn{3}{|c|}{ gluten-free/control } & \multicolumn{3}{|c|}{ gluten/whole-grain } \\
\hline $\mathrm{P}$ & 0.46 & 0.71 & 0.90 & $0.04^{\mathrm{a}}$ & 0.05 & $0.05^{\mathrm{b}}$ \\
\hline significance & & & & $*$ & & $*$ \\
\hline & \multicolumn{3}{|c|}{ gluten/control } & \multicolumn{3}{|c|}{ whole-grain/control } \\
\hline $\mathrm{P}$ & 0.29 & 0.46 & 0.49 & 0.07 & 0.06 & $0.04^{\mathrm{b}}$ \\
\hline significance & & & & & & $*$ \\
\hline
\end{tabular}

Abbreviations: ${ }^{a}$ differences between groups in baseline data; ${ }^{b}$ differences between groups in post-intervention data.

For whole-grain group was characterized the highest mean age (39.7 \pm 8.63 years), which was most likely reflected at the VFA values at the start of the study (Table 1). In comparison with other subgroups, the highest mean VFA values were in whole-grain group (Table 3). Based on these facts we can predict the effect of age on the development of overweight or obesity. During trial VFA values ranged between 40.03-194.33 $\mathrm{cm}^{2}$. After the intervention the baseline mean VFA value was decreased from $91.58 \pm 33 \mathrm{~cm}^{2}$ to $90.47 \pm 34.37 \mathrm{~cm}^{2}$ ( $p>0.05$ ). In comparison with other subgroups wholegrain group had the most of all participants with high or extreme VFA values $(10 \%$ and $3 \%$, respectively, Table $2)$. During the intervention there were no significant changes in the representation of the probands in the VFA categories. From the point of view assessment of the differences between the whole-grain group and the other monitored subgroups we recorded significant differences at the beginning of the study with gluten-free and gluten groups $(\mathrm{P}<0.05)$ and two months after end of consumption with gluten and control groups $(\mathrm{P}<0.05$; Table 4). Whole grains have been inversely associated with body weight and fat distribution $[39,45,53]$. Their beneficial effects may be explained by nutrients that contain. Fiber may decrease energy intake by inducing satiety [27], wheat fiber reduced the risk of diabetes [21, 49]. Whole-grain bakery products have lower glycemic load than white bakery products, which evokes a lower insulin reaction and leads to decreased hunger and energy intake. Researchers found no unfavourable effects on ponderal status when they analysed groups of food items containing whole-grain breads $[33,58]$. Fuente-Arrillaga et al. [14] found inversely association between a higher consumption of whole-grain bread and the risk of overweight or obesity.

Mendez et al. [46] observed no differences between the effects of bread type consumption, while Newby et al. [51] found differences between white or wholegrain bread consumption and its effects on weight gain. Bautista-Castaño et al. [6] suggest that the different composition of whole-grain and white bread have different effects on body weight and abdominal fat.

From the point of view of the impact of gender on VFA we found that the male group had a higher initial mean VFA value compared to a female group $\left(82.29 \pm 35.1 \mathrm{~cm}^{2}\right.$ vs $75.38 \pm 27.96 \mathrm{~cm}^{2}$, respectively; Table 3). During the trial VFA values decreased in both groups and these changes did not differ significantly between the groups or the baseline values. We found the highest VFA value in male group two months after 
the end of consumption $\left(194.33 \mathrm{~cm}^{2}\right)$ and the lowest immediately after the intervention $\left(19.36 \mathrm{~cm}^{2}\right)$. For women, the highest VFA value was $167.22 \mathrm{~cm}^{2}$ after 6 weeks of consumption and the lowest of $32.01 \mathrm{~cm}^{2}$ two months after end of consumption.

The normal range of changes in the VFA of ordinary subjects was $\pm 40 \mathrm{~cm}^{2}$ in the study of Maruyama et al. [43] and Fukui [20] found a maximum change in VFA of $55.9 \mathrm{~cm}^{2}$ after twelve weeks in obese Japanese patients. We observed the greatest change of VFA $13.28 \mathrm{~cm}^{2}$, which in this case meant an increase in VFA in proband in the gluten-free group. In this group, the highest decline in the value of the monitored parameter was $4.39 \mathrm{~cm}^{2}$. In other groups the changes were as follows: in gluten group the greatest increase of VFA was $10.19 \mathrm{~cm}^{2}$ and decrease $8.57 \mathrm{~cm}^{2}$, in the whole-grain group the maximum VFA growth was by $8.57 \mathrm{~cm}^{2}$ and the decrease by $11.83 \mathrm{~cm}^{2}$, in the control group the maximum increase was by $8.32 \mathrm{~cm}^{2}$ and a reduction by $8.26 \mathrm{~cm}^{2}$. Increasing accumulation of visceral fat is associated with worsening of cardiovascular disease, linearly correlated with the prevalence of hypertension, elevated fasting glucose levels [19]; reduction may prevent future stroke and dementia. The exclusion of bread and bakery products from the diet may lead to unhealthy nutritional foods being included into the dietary patterns. Finally, it is important that the consumption of bread has continued to fall in the world over the past decades but world epidemic of obesity has been increasing $[61,68]$.

\section{CONCLUSIONS}

In our study, we observed the effect of consumption of different kinds of bakery products on visceral fat area. We found that while gluten-free and gluten bakery products increased VFA values mainly in participants with low values of VFA, in participants with higher levels of VFA caused consumption of whole-grain bakery products decrease of VFA. During six-week consumption of gluten-free and gluten-containing bakery products we found increase of mean VFA values in both groups, but these changes were not significant. Mean value of VFA of whole-grain group was during trial decreased without significant change. Further research is needed to monitor the effect of whole-grain bakery products on VFA in the population with low VFA and consumption of gluten-free and gluten-containing bakery products on subjects with high VFA values.

\section{Acknowledgements}

This study was supported by the Unia Priemyselných Pekárov Slovenska and by the project ITEBIO (ITMS 26220220115). We thank especially to Mr Vladislav Baričák, all participants of the study and the staff of the Department of Human Nutrition at Slovak University of Agriculture in Nitra Slovakia.

\section{Conflict of interest}

The authors declare no conflict of interest.

\section{REFERENCES}

1. Abulmeaty, M.A., Ahmed, S., Almajwal, A.: Apelin is promising in management of diabetes complicating high fat diet induced obesity in rats. Prog Nutr. 2013;15(4):245-254.

2. Alvarez-Jubete, L., Arendt, E.K., Gallagher, E.: Nutritive value of pseudocereals and their increasing use as functional gluten-free ingredients. Trends in Food Science \& Technology 2010;21(2):106-113. DOI: https:// doi.org/10.1016/j.tifs.2009.10.014

3. Andersson, H., Öhgren, C., Johansson, D., Kniola, M., Stading, M.: Extensional flow, viscoelasticity and baking performance of gluten-free zein-starch doughs supplemented with hydrocolloids. Food Hydrocoll. 2011;25(6):1587-1595. DOI: https://doi. org/10.1016/j.foodhyd.2010.11.028

4. Aston, L.M., Stokes, C.S., Jebb, S.A.: No effect of a diet with a reduced glycaemic index on satiety, energy intake and body weight in overweight and obese women. Int. J. Obes. 2008;32:160-165. DOI: https:// doi.org/10.1038/sj.ijo.0803717

5. Babiarczyk, B., Turbiarz, A.: Body Mass Index in elderly people - do the reference ranges matter? Progress in Health Sciences 2012;2(1):58-67.

6. Bautista-Castaño, I., Sánchez-Villegas, A., Estruch, R., Martínez-González, M.A., Corella, D., Salas-Salvadó, J., Covas, M.I., Schroder, H., Alvarez-Pérez, J., Quilez, J., Lamuela-Raventós, R.M., Ros, E., Arós, F., Fiol, M., Lapetra, J., Muñoz, M.A., Gómez-Gracia, E., Tur, J., Pintó, X., Ruiz-Gutierrez, V., PortilloBaquedano, M.P., Serra-Majem, L.: Changes in bread consumption and 4-year changes in adiposity in Spanish subjects at high cardiovascular risk. Br. J. Nutr. 2013;110(2):337-346. DOI: https://doi.org/10.1017/ S000711451200476X

7. Beavers, K.M., Beavers, D.P., Nesbit, B.A., Ambrosius, W.T., Marsh, A.P., Nicklas, B.J., Rejeski, W.J.: Effect of an 18 month physical activity and weight loss intervention on body composition in overweight and obese older adults. Obesity (Silver Spring) 2014;22(2):325231. DOI: http://dx.doi.org/10.1002/oby.20607

8. Beunza, J.J., Toledo, E., Hu, F.B., Bes-Rastrollo, M., Serrano-Martínez, M., Sánchez-Villegas, A., Martínez, J.A., Martínez-González, M.A.: Adherence, the Mediterranean diet, long-term weight change, and incident overweight or obesity: the Seguimiento Universidad de Navarra (SUN) cohort. Am J Clin Nutr. 2010;92(6):1-8. DOI: 10.3945/ajen.2010.29764

9. Bonder, M.J., Tigchelaar, E.F., Cai, X., Trynka, G., Cenit, M.C., Hrdlickova, B., Zhong, H., Vatanen, T., Gevers, D., Wijmenga, C., Wang, Y., Zhernakova, A.: The influence of a short-term gluten-free diet on the human gut microbiome. Genome Med 2016;8:45. DOI: 10.1186/s13073-016-0295-y

10. Burě̌ová, I., Tokár, M., Mareček, J., Hřivnac, L., Famérad, O., Šottniková, V.: The comparison of the 
effect of added amaranth, buckwheat, chickpea, corn, millet and quinoa flour on rice dough rheological characteristics, textural and sensory quality of bread. Journal of Cereal Science 2017;75:158-164. DOI: http:// dx.doi.org/10.1016/j.jcs.2017.04.004

11. Catassi, C., Bai, J.C., Bonaz, B., Bouma, G., Calabrò, A., Carroccio, $A$. et al.: Non-celiac gluten sensitivity: the new frontier of gluten related disorders. Nutrients 2013;5:38393853. DOI: $10.3390 /$ nu5103839

12. Conte, P., Fadda, C., Piga, A., Collar, C.: Technofunctional and nutritional performance of commercial breads available in Europe. Food Sci Technol Int. 2016;22:621-633. DOI: 10.1177/1082013216637724

13. Dar, Y.: Advances and ongoing challenges in the development of gluten-free baked goods. Cereal Foods World 2013;58(6):298-304. DOI: 10.1094/CFW-58-60298

14. de la Fuente-Arrillaga, C., Martinez-Gonzalez, M.A., Zazpe, I., Vazquez-Ruiz, Z., Benito-Corchon, S., BesRastrollo, M.: Glycemic load, glycemic index, bread and incidence of overweight/obesity in a Mediterranean cohort: the SUN project. BMC Public Health 2014;14(1091). DOI: https://doi.org/10.1186/14712458-14-1091

15. De Lorenzo, A., Del Gobbo, V., Premrov, M.G., Bigioni, M., Galvano, F., Di Renzo, L.: Normal-weight obese syndrome: early inflammation? The American Journal of Clinical Nutrition 2007;85(1):40-45.

16. Dodevska, M.S., Djordjevic, B.I., Sobajic, S.S., Miletic, I.D., Djordjevic, P.B., Dimitrijevic-Sreckovic, V.S.: Characterisation of dietary fibre components in cereals and legumes used in Serbian diet. Food Chem. 2013;141(3):1624-1629. DOI: 10.1016/j.foodchem.2013.05.078.

17. Elli, L., Branchi, F., Tomba, C., Villalta, D., Norsa, L., Ferretti, F., Roncoroni, L., Bardella, M.T.: Diagnosis of gluten related disorders: celiac disease, wheat allergy and non-celiac gluten sensitivity. World J Gastroenterol 2015;21:7110-7119. DOI: 10.3748/wjg.v21.i23.7110

18. Foschia, M., Horstmann, S., Arendt, E.K., Zannini, E.: Nutritional therapy - Facing the gap between coeliac disease and gluten-free food. International Journal of Food Microbiology 2016;239:113-124. DOI: http://dx.doi. org/10.1016/j.ijfoodmicro.2016.06.014

19. Fox, C.S., Massaro, J.M., Hoffmann, U., Pou, K.M., Maurovich-Horvat, P., Liu, C.Y., Vasan, R.S., Murabito, J.M., Meigs, J.B., Cupples, L.A., D’Agostino, R.B. Sr, O'Donnell, C.J.: Abdominal visceral and subcutaneous adipose tissue compartments: Association with metabolic risk factors in the Framingham Heart Study. Circulation 2007;116(1):39-48. DOI: https://doi.org/10.1161/CIRCULATIONAHA.106.675355

20. Fukui, T.: Importance of measurement of fasting immunoreactivity insulin and interpretation of its results. Ningen Dock 2011;25:7-14. DOI: https://doi.org/10.11320/ ningendock. 25.7

21. Fung, T.T., Hu, F.B., Pereira, M.A., Liu, S., Stampfer, M.J., Colditz, G.A., Willett, W.C.: Whole-grain intake and the risk of type 2 diabetes: a prospective study in men. Am J Clin Nutr. 2002;76(3):535-540.
22. Gaesser, G.A., Angadi, S.S.: Navigating the glutenfree boom. JAAPA 2016;28:1-7. DOI: 10.1097/01. JAA.0000469434.67572.a4

23. Gažarová, M., Chlebová, Z., Kopčeková, J., Lenártová, P., Holovičová, M.: The influence of gluten-free bakery products consumption on selected anthropometric parameters. Potravinarstvo Slovak Journal of Food Sciences 2017;11(1):761-769. doi: https://doi. org/10.5219/861

24. Gelski, J.: Getting a grip on gluten-free growth. Available from: FoodBusinessNews.net, Jul. 24, 2015. (Accessed 12/15/2017)

25. Gumul, D., Berski, W., Ivanišová, E., Gambuś, H., Kačániová, M., Harangózo, L., Tokár, M.: Characteristics of starch breads enriched with red potatoes. Potravinarstvo Slovak Journal of Food Sciences 2017;11(1):162-166. DOI: https://dx.doi. org/10.5219/720

26. Hamer, R.J.: Coeliac disease: Background and biochemical aspects. Biotechnology Advances 2005;23(6):401-408. DOI: https://doi.org/10.1016/j. biotechadv.2005.05.005

27. Howarth, N.C., Saltzman, E., Roberts, S.B.: Dietary fiber and weight regulation. Nutr Rev. 2001;59(5):129139.

28. Inabnet, W.B., Winegar, D.A., Sherif, B., Sarr, M.G.: Early outcomes of bariatric surgery in patients with metabolic syndrome: an analysis of the bariatric outcomes longitudinal database, J. Am. Coll. Surg. 2012;214(4):550556. DOI: 10.1016/j.jamcollsurg.2011.12.019

29. Janssen, I., Katzmarzyk, P.T., Ross, R.: Waist circumference and not body mass index explains obesity-related health risk. Am J Clin Nutr. 2004;79(3):379-384.

30. Jenkins, D.J., Wesson, V., Wolever, T.M., Jenkins, A.L., Kalmusky, J., Guidici, S., Csima, A., Josse, R.G., Wong, G.S.: Wholemeal versus wholegrain breads: proportion of whole or cracked grain and the glycaemic response. BMJ 1988;297(6654):958-960.

31. Jensen, M.D., Ryan, D.H., Apovian, C.M., Ard, J.D., Comuzzie, A.G., Donato, K.A., Hu, F.B., Hubbard, V.S., Jakicic, J.M., Kushner, R.F., Loria, C.M., Millen, B.E., Nonas, C.A., Pi-Sunyer, F.X., Stevens, J., Stevens, V.J., Wadden, T.A., Wolfe, B.M., Yanovski, S.Z., Jordan, H.S., Kendall, K.A., Lux, L.J., Mentor-Marcel, R., Morgan, L.C., Trisolini, M.G., Wnek, J., Anderson, J.L., Halperin, J.L., Albert, N.M., Bozkurt, B., Brindis, R.G., Curtis, L.H., DeMets, D., Hochman, J.S., Kovacs, R.J., Ohman, E.M., Pressler, S.J., Sellke, F.W., Shen, W.K., Smith, S.C. Jr., Tomaselli, G.F.: 2013 AHA/ACC/TOS guideline for the management of overweight and obesity in adults: a report of the American college of cardiology/American heart association task force on practice guidelines and the obesity society. Circulation 2014;129(25 Suppl):102-138. DOI: 10.1161/01.cir.0000437739.71477. ee.

32. Juntunen, K.S., Niskanen, L.K., Liukkonen, K.H., Poutanen, K.S., Holst, J.J., Mykkänen, H.M.: Postprandial glucose, insulin, and incretin responses, grain products in healthy subjects. Am J Clin Nutr. 2002;75(2):254262. 
33. Koh-Banerjee, P., Franz, M., Sampson, L., Liu, S., Jacobs, D.R. Jr, Spiegelman, D., Willett, W., Rimm, E. Changes in whole-grain, bran, and cereal fiber consumption in relation, 8-y weight gain among men. Am J Clin Nutr. 2004;80(5):1237-1245.

34. Kolesárová, A., Zeleňáková, L., Gažarová, M., Cesneková, $S$.: Konzumácia pekárskych výrobkov. In: Hygiena a technologie potravin - XLVII. Lenfeldovy a Höklovy dny: sborník přednášek a posterů, Veterinární a farmaceutická univerzita Brno, 18.-19.10. 2017. p. 165-170. ISBN 978-80-7305-793-0 (in Slovak)

35. Krauss, R.M., Eckel, R.H., Howard, B., Appel, L.J., Daniels, S.R., Deckelbaum, R.J., Erdman, J.W. Jr, KrisEtherton, P., Goldberg, I.J., Kotchen, T.A., Lichtenstein, A.H., Mitch, W.E., Mullis, R., Robinson, K., Wylie-Rosett, J., St Jeor, S., Suttie, J., Tribble, D.L., Bazzarre, T.L.: AHA dietary guidelines: revision 2000: a statement for healthcare professionals from the Nutrition Committee of the American Heart Association. Circulation 2000;102(18):2284-2299.

36. Kuk, J.L., Lee, S., Heymsfield, S.B., Ross, R.: Waist circumference and abdominal adipose tissue distribution: Influence of age and sex. The American Journal of Clinical Nutrition 2005;81(6):1330-1334.

37. Lean, M.E., Han, T.S., Prvan, T., Richmond, P.R., Avenell, A.: Weight loss with high and low carbohydrate $1200 \mathrm{kcal}$ diets in free living women. Eur. J. Clin. Nutr. 1997;51:243-248. DOI: https://doi.org/10.1038/ sj.ejcn.1600391

38. Liu, S., Willett, W.C., Manson, J.E., Hu, F.B., Rosner, B., Colditz, G.: Relation between changes in intakes of dietary fiber and grain products and changes in weight and development of obesity among middle-aged women. Am J Clin Nutr. 2003;78(5):920-927.

39. Liu, S., Willett, W.C., Manson, J.E., Hu, F.B., Rosner, B., Colditz, G.: Relation between changes in intakes of dietary fiber and grain products and changes in weight and development of obesity among middle-aged women. Am J Clin Nutr. 2003;78(5):920-927.

40. López Sobaler, A.M., Ortega, R.M., Aparicio, A., Bermejo, L.M., Rodríguez Rodríguez, E.: Concerns about body weight. National study on related mistakes and habits. In: R. M. Ortega (Ed.) Nutrition in the females population. Madrid, Spain : Ergón 2007;39-50.

41. Malinauskas, B.M., Raedeke, T.D., Aeby, V. G., Smith, J.L., Dallas, M.B.: Dieting practices, weight perceptions, and body composition: a comparison of normal weight, overweight, and obese college females. Nutr. J. 2006;5(11). DOI: https://doi.org/10.1186/1475-28915-11

42. Martin, J., Geisel, T., Maresch, C., Krieger, K., Stein, $J .:$ Inadequate nutrient intake in patients with celiac disease: results from a german dietary survey. Digestion 2013;87:240-246.

43. Maruyama, M., Fukui, T., Yamauchi, K., Fukami, T., Miyamoto, Y., Yasuda, T., Yoshitaka, S., Abe, Y.: Evaluation of association between changes in various lifestylerelated disease parameters and changes in visceral fat. Ningen Dock 2010;25:42-47. DOI: https://doi. org/10.11320/ningendock.25.638
44. Mazzeo, T., Cauzzi, S., Brighenti, F., Pellegrini, N.: The development of a composition database of glutenfree products. Public Health Nutr. 2014;18:1353-1357. DOI: $10.1017 / \mathrm{S} 1368980014001682$

45. McKeown, N.M., Meigs, J.B., Liu, S., Wilson, P.W., Jacques, P.F.: Whole-grain intake is favorably associated with metabolic risk factors for type 2 diabetes and cardiovascular disease in the Framingham Offspring Study. Am J Clin Nutr. 2002;76(2):390-398.

46. Mendez, M.A., Popkin, B.M., Jakszyn, P., Berenguer, A., Tormo, M.J., Sanchéz, M.J., Quirós, J.R., Pera, G., Navarro, C., Martinez, C., Larrañaga, N., Dorronsoro, M., Chirlaque, M.D., Barricarte, A., Ardanaz, E., Amiano, P., Agudo, A., González, C.A.: Adherence, a Mediterranean diet is associated with reduced 3-year incidence of obesity. J Nutr. 2006;136(11):2934-2938.

47. Mintel 2015: Database: Gluten-free foods US (URL: http://www.mintel.com/), last accessed 12/12/2017.

48. Miranda, J., Lasa, A., Bustamante, M.A., Churruca, I., Simon, E.: Nutritional Differences Between a Glutenfree Diet and a Diet Containing Equivalent Products with Gluten. Plant Foods Hum Nutr. 2014;69:182-187. DOI: 10.1007/s11130-014-0410-4

49. Montonen, J., Knekt, P., Jarvinen, R., Aromaa, A., Reunanen, A.: Whole-grain and fiber intake and the incidence of type 2 diabetes. Am J Clin Nutr. 2003;77(3):622-629.

50. Nanditha, B., Prabhasankar, P.: Antioxidants in bakery products: A review. Critical Reviews in Food Science and Nutrition 2009;49(1):1-27. DOI: https://doi. org/10.1080/10408390701764104

51. Newby, P.K., Muller, D., Hallfrisch, J., Andres, R., Tucker, K.L.: Food patterns measured by factor analysis and anthropometric changes in adults. Am J Clin Nutr. 2004;80(2):504-513.

52. Pellegrini, N., Agostoni, C.: Nutritional aspects of gluten-free products. J. Sci. Food Agric. 2015;95(12):23802385. DOI: $10.1002 /$ jsfa.7101

53. Pereira, M.A., Jacobs, D.R. Jr, Pins, J.J., Raatz, S.K., Gross, M.D., Slavin, J.L., Seaquist, E.R.: Effect of whole grains on insulin sensitivity in overweight hyperinsulinemic adults. AmJ Clin Nutr. 2002;75(5):848855.

54. Rea, F., Polito, C., Marotta, A., Di Toro, A., Iovene, A., Collini, R., Rea, L., Sessa, G.: Restoration of body composition in celiac children after one year of gluten-free diet. J Pediatr Gastroenterol Nutr 1996;23:408-412.

55. Roberts, S.B., Heyman, M.B.: Dietary composition and obesity: do we need to look beyond dietary fat? J Nutr. 2000;130(2S Suppl):267S (editorial).

56. Romaguera, D., Ängquist, L., Du, H., Jakobsen, M.U., Forouhi, N.G., Halkjoer, J., Feskens, E.J., van $\operatorname{der} A$, D.L., Masala, G., Steffen, A., Palli, D., Wareham, N.J., Overvad, K., Tjønneland, A., Boeing, H., Riboli, E., Sørensen, T.I.: Food composition of the diet in relation, changes in waist circumference adjusted for body mass index. PLoS One 2011;6(8):23384. DOI: 10.1371/journal.pone. 0023384

57. Sabanis, D., Lebesi, D., Tzia, C.: Effect of dietary fibre enrichment on selected properties of gluten-free bread. 
LWT Food Sci. Technol. 2009;42(8):1380-1389. DOI: https://doi.org/10.1016/j.lwt.2009.03.010

58. Schulz, M., Nöthlings, U., Hoffmann, K., Bergmann, M.M., Boeing, H.: Identification of a food pattern characterized by high-fiber and low-fat food choices associated with low prospective weight change in the EPICPotsdam Cohort. J Nutr. 2005;135(5):1183-1189.

59. Segura, M.E., Rosell, C.M.: Chemical composition and starch digestibility of different gluten-free breads. Plant Foods Hum Nutr 2011;66:224-230.

60. Seidell, J.C., Perusse, L., Despres, J.P., Bouchard, C.: Waist and hip circumferences have independent and opposite effects on cardiovascular disease risk factors: the Quebec Family Study. Am J Clin Nutr. 2001;74(3):315321.

61. Serra-Majem, L., Raido Quintana, B.: Consumo de pan en el mundo y en Espan a (Bread consumption in the world and in Spain). In: Libro Blanco del Pan (Bread's White Book) 2010;pp. 63-77 [A Gil and L Serra-Majem, editors]. Madrid: Ed Med Panamericana.

62. Shan, L., Molberg, Ø., Parrot, I., Hausch, F., Filiz, F., Gray, G.M., Sollid, L.M., Khosla, C.: Structural basis for gluten intolerance in celiac sprue. Science 2002;297(5590):2275-2279. DOI: $10.1126 /$ science. 1074129

63. Shepherd, S.J., Gibson, P.R.: Nutritional inadequacies of the gluten-free diet in both recently-diagnosed and long-term patients with coeliac disease. J Hum Nutr Diet 2013;26:349-358.

64. Shewry, P.R., Lovegrove, A.: Exploiting natural variation to improve the content and composition of dietary fibre in wheat grain: A review. Acta Alimentaria 2014;43(3):357-372. DOI: https://doi.org/10.1556/ AAlim.43.2014.3.1

65. Slavin, J.L., Martini, M.C., Jacobs, D.R. Jr, Marquart, $L .:$ Plausible mechanisms for the protectiveness of whole grains. Am J Clin Nutr. 1999;70(3 suppl):459-463.

66. Staudacher, H.M., Gibson, P.R.: How healthy is a gluten-free diet?. Br J Nutr. 2015;114:1539-1541. DOI: 10.1017/S000711451500330X

67. Wiklund, P., Alen, M., Munukka, E., Cheng, S.M., Yu, B., Pekkala, S., Cheng, S.: Metabolic response to 6-week aerobic exercise training and dieting in previously sedentary overweight and obese pre-menopausal women: A randomized trial. Journal of Sport and Health Science 2014;3:217-224. DOI: http://dx.doi.org/10.1016/j. jshs.2014.03.013

68. World Health Organization: Obesity: Preventing and Managing the Global Epidemic. Report of a WHO Consultation. WHO Technical Report Series no. 894. Geneva: WHO 2000.

Received: 08.06.2018

Accepted: 21.08.2018

This article is available in Open Access model and licensed under a Creative Commons Attribution-Non Commercial 3.0.Poland License (CC-BY-NC) available at: http://creativecommons.org/licenses/by-nc/3.0/pl/deed.en 